DOI 10.37882/2223-2982.2021.09.29

\title{
СИНОНИМИЧЕСКИЕ ЗООНИМЫ В ЭВЕНСКОМ ЯЗЫКЕ
}

\section{SYNONYMOUS ZOONYMS IN THE EVEN LANGUAGE}

I. Sadovnikova

Summary: This article is devoted to synonymous zoonyms in the Even language. The relevance of the study lies, first of all, in the fact that synonyms have not yet received sufficient coverage in the Even language, which contribute to the development of the lexical system of the language, and the identified specific features of zoonyms are of particular value in typological studies of various languages.

Keywords: even language, synonyms, synonymic series.
Садовникова Ия Ивановна

К.филол.н., м.н.с., Институт гуманитарных исследований и проблем малочисленных народов Севера, Сибирское отделение Российской академии наук, г. Якутск Sadovnikova79@mail.ru

Аннотация: Данная статья посвящена синонимическим зоонимам в эвенском языке. Актуальность исследования заключается, прежде всего, в том, что синонимы не получили до сих пор достаточного освещения в эвенском языке, которые способствуют развитию лексической системы языка, а выявленные специфические особенности зоонимов представляют особую ценность при типологических исследованиях различных языков.

Ключевые слова: эвенский язык, синонимы, синонимические ряды.

Синонимия в эвенском языке еще не приобрела соответствующего научного освещения. Вопросы синонимии эвенском языке рассматривались лишь в нескольких статьях, а также, весьма поверхностно, в ряде учебников и учебных пособиях по родному языку [7]. Собранный и описанный нами материал по зоонимам в плане содержания и оформления используется при составлении словаря синонимов, которым в данное время занимается автор. Практически полезный для пользования словарь синонимов может быть использован в дальнейших лингвистических исследованиях, а также во внеклассной и научной работе в школе по эвенскому языку. В подгруппу лингвистических структурно-связанных синонимов, обладающих слабой взаимозаменяемостью в контексте, входят диалектные синонимы из западных говоров. Диалектная структура эвенского языка сложная. Зафиксированы три больших наречия: западное, среднее и восточное. В этих наречиях специалисты-эвеноведы выделяют около двадцати говоров и диалектов [9, с.11]. Характеристика диалектизмов, таким образом, вариативна, причем столкновение разнодиалектных слов порождает в первую очередь дублеты, которые затем переходят в синонимы.

Ввиду того, что синонимы по своей формальной структуре представляют собой объединения словесных единиц, возникает необходимость проведения анализа их структуры на двух различных уровнях, на системном уровне - это синонимический ряд, и на элементном уровне - это слово. В качестве исходного слова синонимического ряда выступает стилистически нейтральная единица, являющаяся простым наименованием, без какого-либо оценочного момента по отношению к тому, что ею называется [10, с.55]. А.А. Брагина считает, что устаревшие слова и выражения могут появиться в речи с новым значением в других семантических связях: «Синонимический ряд, как известно, считается явлением 
синхронным, присущим одному временному периоду. Это бесспорное положение надо, однако, сопроводить оговоркой: с одной стороны, синонимический ряд соединяют с прошлым архаизмы, функционирующие в высоком стиле и бытующие в классической литературе; с другой - синонимизирующиеся новые слова и новые оттенки значений старых слов «держат открытой его границу» для будущих языковых движений» [1,с.65]. Как показывает, фактологический материал в эвенском языке преобладают двухчленные и трехчленные синонимические ряды зоонимов, например: абаңуанилчакар ойис "медвежата";

гикар гусэтэ "орел";

гилрак тотем. тэгэм тотем. хукэчэн "медведь не залегший в берлогу";

горната делики "горнастай";

гякан көсчэн мукрукалдывун "ястреб";

гяки тураки "ворона";

дабаня зап. оран хямчуң "олень";

ганипа гулкэ "годовалый о животных";

илаглика ниглий зап. наңуандя эрбэч "гусь";

кабяв кабдяка текчакан "куропатка";

кадива каңадя"маленькая чайка";

каккаря нуслимэ өкэнээ "гагара";

кани хуркэч хутукас "медведица";

кидак чиввек"цапля";

конкуки кирич "дятел";

кукэки кэкучэн "кукушка";

мандарка мөтэкэ "тюлэнь";

мэкКИччэ нэллэн чөкчэңџэ "кулик";

некичэн нунки "утка";

онаки энсичэн "росамаха";

өлики өрэк "белка";

хонцуачан энкэчэн "оленёнок";

чамакчан нэкичэ "мышка";

энтмири хөрики "глухарь".

Синонимический ряд зоонимов включающий четыре и более компонентов, для эвенского языка менее характерны. В исследуемом материале их незначительное количество, например:

кулар никчан ниңучан өми̧эты "большая белая чайка";

нёган нёрук нэвулун ондат "олень вожак";

навдака зап. нөкэчэн токи эгдетэ "лось".

семичленные синонимические ряды:

буркучан гиркари г гиркучан долбасак нёцччак нэлуки хевунки иносказ. "волк". Наименование медведя в эвенском языке представлен многочленным синонимическим рядом: абаңза кяга мэмэкэ мэмэнньдэ нугдэне накат этки этэ дэрикэн тотем. кобалан тотем. көлэңэт тотем. умалаңза тотем. хермит тотем. хучана тотем. $\sim$ хэвче тотем. хэвэйэ тотем., "медведь". Данный результат связан с тем, что медведь играл большую роль в эвенской мифологии, его почитали и уважали. И по сей день почтительное отношение эвенов к медведю проявляется в их традициях и обычаях. Переименование животного связано с табу - запретом прямого называния, основанным на вере в магическую силу слова и имени, в то, что слово или имя вызывает его явиться к произносящему. Почитание, включающее в себя запрет на произношении сохраняется как этическая норма общении и поведении людей.

Синонимы - заимствования в эвенском языке в количественном отношении немногочисленны, многие названия зоонимов пришли из русского языка, сюда вошли зоонимы: берблют рус. бөкчэрэ делгэнкэ "верблюд"; боробей рус. чивкэчэн "воробей" и т.д. Из якутского языка, заимствованно лишь одно слово: кэрэмри як. кэрэмэс "чернобурка". Как следует из вышеприведенных примеров, заимствованные единицы могут занимать положение доминанты, вытесняя исконное слово на вторую позицию. Заимствования, из русского языка употребляясь в различных речевых сферах, приобретают соответствующую стилевую окраску. В использовании в разговорной речи они, как правило, претерпевают фонетическую и морфологическую адаптацию, изменив принимающий язык не только количественно, но и качественно. Образованию синонимических рядов также способствуют окрас животных, название масти, крик птиц, животных, возраст и т.д., например: негчэне хонаня муңрин нугдэне мэңти "серо-бурый" о масти;

хакарин хаңра хонаня чилэне "черный, темный" о масти;

накатас утэс "шкура медведя";

мулка ганипа гулкэ "годовалый" о животном;

кинякалкан хогдилкан "хвостатый";

ниргэн эңтин "хорканье оленя";

нярадай иркадай "крик водоплавающих птиц" и т.д.

Анализ структуры исследуемого материала проводился на системном уровне. Объектом изучения на системном уровне выступал синонимический ряд, под которым понимается два и более лексических синонимов, соотносимых между собой при образовании одних и тех же зоонимов, которые образуют в языке определенную группу. В эвенском языке, как показывает проработанный материал, преобладают двухчленные и трехчленные синонимические ряды.

В заключении подчеркнем, что предпринятая работа, по сути, является первым опытом исследования синонимов эвенского языка. Синонимические зоонимы были рассмотрены нами в достаточно общем плане. В дальнейшем представляется целесообразным обратиться к более глубокому изучению структуры и семантики различных синонимических типов, а также проследить особенности функционально-стилевого использования синонимов. 


\section{Список сокрашений: \\ заn. - диалектное слово из западных говоров \\ иносказ. - иносказательно}

рус. - русский

тотем. - тотемное (слово)

як - якутский.

\section{ЛИТЕРАТУРА}

1. Брагина А.А. Синонимы в литературном языке. М.: Наука, 1986. С.128.

2. Будагов Р.А. Литературные языки и языковые стили. М.: Высшая школа, 1967. - С.376.

3. Григорьев А.Д. Заметки о лексической синонимии// Вопросы культуры речи. М.: АН СССР, 1959. Вып.2. С.7-30.

4. Гречко В.А. Лексическая синонимика современного русского литературного языка. Саратов: Изд-во Саратовского ун-та, 1987. С.151

5. Евгеньева А.П. словарь синонимов русского языка: в 2-х томах Л.: Наука, 1970. Т.1-2. С.656.

6. Лингвистический энциклопедический словарь; гл. ред. В.Н. Ярцева. М.. Сов. энциклопедия. 1990. С.685.

7. Новикова К.А., Гладкова Н.И., Роббек В.А. Эвенский язык: Учеб. для пед. Уч-щ. Л.: Просвещение. 1991. С.304.

8. Палевская М.Ф. Синонимы в русском языке. М.: Просвещение. 1964. С.128.

9. Роббек В.А., Роббек М.Е. Эвенско-русский словарь. - Н.: Наука, 2004. С. 356.

10. Шанский Н.М. Лексикология современного русского языка. Пособие для студентов пед. Ин-тов. 2-е изд., испр. М.:Просвещение, 1972. С.328.

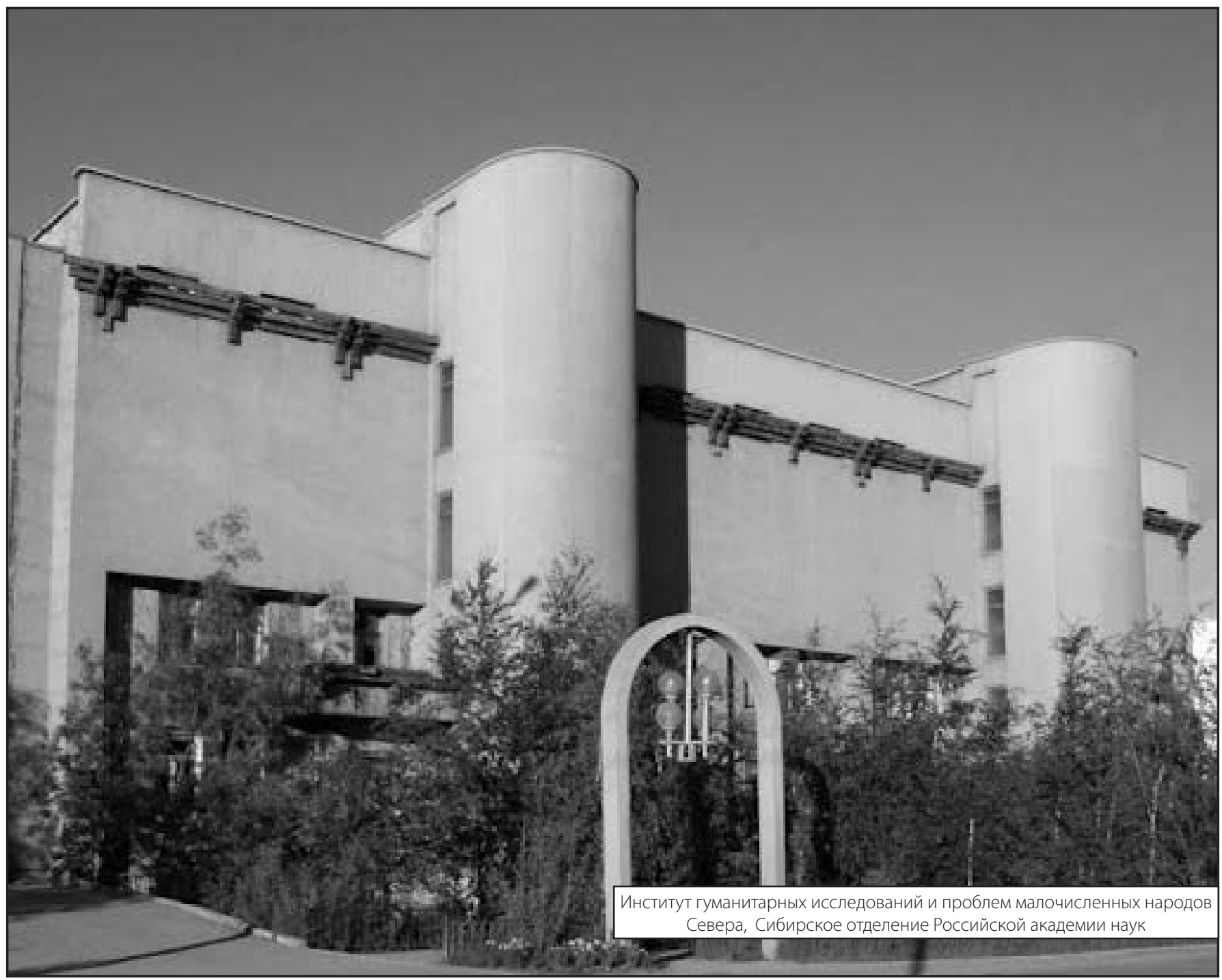

